\title{
TNFSF15 wt Allele
}

National Cancer Institute

\section{Source}

National Cancer Institute. TNFSF15 wt Allele. NCI Thesaurus. Code C50967.

Human TNFSF15 wild-type allele is located within 9q32 and is approximately $17 \mathrm{~kb}$ in length. This allele, which encodes tumor necrosis factor ligand superfamily member 15 protein, plays a role in the inhibition inhibits endothelial cell proliferation and angiog enesis.

This allele is also involved in the induction of endothelial cell apoptosis. 